\title{
Lessons for neurologists from the United Kingdom Third National Morbidity Survey
}

\author{
ANTHONY HOPKINS \\ From the Research Unit, Royal College of Physicians, London
}

SUMmaRY The Third National Morbidity Survey lists data about the primary care consultations for more than 300,000 person-years at risk. Data of interest to neurologists have been extracted from the complex tables of the Survey, many of which are on micro-fiche. Assuming that any one subject has only one neurological symptom, $9 \cdot 5 \%$ of the population will consult their general practitioner about a neurological symptom each year. The five most common groups of disorders for which advice is sought are headache/migraine, dizziness, syndromes related to the cervical or lumbar spine, faints or fits, and symptoms due to cerebrovascular disease. About $7 \%$ of all patients seen with neurological symptoms are referred to hospital clinics for further advice.

Family doctors (general practitioners) in the United Kingdom (UK) have collaborated with the Office of Population Censuses and Surveys to produce over the years three surveys of morbidity in the community. ${ }^{1-3}$ The Third National Morbidity Survey has recently been published, based upon data collected on over 300000 person-years at risk. An analysis of some of the complex tables in the survey, which provide information rates about morbidity due to all diseases, may be helpful to neurologists when planning their provision of services.

\section{Methods}

Information was obtained at the time of consultation on the morbidity of 307803 person years at risk in 48 general practices (143 doctors). The distribution of ages in these practices reflected closely the distribution of age and sex of the total population of the UK. The data were collected in 1981-82, but coding and computing delayed publication until 1986. The data have been published in bulky tables and in micro-fiche, from which the data relevant to neurologists have been selected.

\section{Results}

In one year, $65 \%$ of all men and $77 \%$ of all women saw their family doctor at least once. The average number

Address for reprint requests: Anthony Hopkins, Research Unit, Royal College of Physicians, 11 St Andrew's Place, London NWI 4LE, UK.

Received 27 July 1988.

Accepted 8 November 1988 of consultations per year was 2.7 for men and 4.0 for women.

Table 1 shows the patient consulting rates per year for various neurological syndromes and diseases of the nervous system, coded according to the codes of the Royal College of General Practitioners and Intere national Classification of Diseases (9th Revision). The syndromes are listed in their rank order of patien consulting rates, with the exception of syncope and "convulsions" which have been placed next to epilepsy for interest's sake. Figures in brackets are those from the 2nd National Morbidity Survey, ${ }^{2}$ used where current figures are not available. The sum of the patient consulting rates in column 6 is 95.0 . Expressed another way, assuming that any one patient has only one neurological disorder, $9.5 \%$ of the population will consult their general practitioner about a neurological symptom in any one year, a figure very similar to that reported from Greece, $12.3 \%{ }^{4}$ The sum of the entries in column 4 shows that there will be 175.2 consultations per year for neurological symptoms per 1000 persons at risk.

Much more detail is available in the original tables. For example, the age specific consulting rate for females with migraine was 5.7 per 1000 females at risk age 5-14, 14.3 age 15-24, 17.6 age 25-44, 14.1 age 45$64,4 \cdot 7$ age $65-74$ and $1 \cdot 7$ age more than 75 . In the two decades age 25-44 years, the person consulting rate for women with migraine was, at 17.6 per 1000 women at risk, nearly three times that for men (6.2 per 1000).

Referral rates for an inpatient admission, outpatient opinion, to the Accident and Emergency Department or for a private or domiciliary consultation are 
Table 1 Patient consulting rates for various neurological syndromes and diseases of the nervous system

\begin{tabular}{|c|c|c|c|c|c|c|c|c|c|}
\hline Disorder & $\begin{array}{l}2 \\
\text { College } \\
\text { code }\end{array}$ & $I C D$ & $\begin{array}{l}4 \\
\text { Consu } \\
\text { rates } \\
\text { person } \\
\text { (table }\end{array}$ & $\begin{array}{l}\text { ultations- } \\
\text { per 1000 } \\
\text { ns at risk } \\
\text { e 13) }\end{array}$ & $\begin{array}{l}5 \\
\text { Episodt } \\
\text { rates pe } \\
\text { persons } \\
\text { (table }\end{array}$ & $\begin{array}{l}\text { de incidence- } \\
\text { per } 1000 \\
\text { ns at risk } \\
\text { 8) }\end{array}$ & $\begin{array}{l}6 \\
\text { Patien } \\
\text { rates } p \\
\text { person } \\
\text { (table }\end{array}$ & $\begin{array}{l}\text { nts consulting- } \\
\text { per } 1000 \\
\text { ns at risk } \\
\text { (18) }\end{array}$ & $\begin{array}{l}7 \\
\text { Referrals-per } \\
\text { cent of patients } \\
\text { consulting } \\
\text { (tables } 11+35)\end{array}$ \\
\hline $\begin{array}{l}\text { Headache } \\
\text { Tension headache }+ \\
\text { "psychogenic backache, } \\
\text { pain of psychic origin" }\end{array}$ & $\begin{array}{l}414 \\
124\end{array}$ & $\begin{array}{l}784 \cdot 0 \\
307.8\end{array}$ & $\begin{array}{r}17 \cdot 4 \\
6 \cdot 0\end{array}$ & $36 \cdot 2^{*}$ & $\left.\begin{array}{r}11 \cdot 9 \\
3 \cdot 3\end{array}\right\}$ & $20 \cdot 5^{*}$ & $\left.\begin{array}{r}13 \cdot 2 \\
4 \cdot 1\end{array}\right]$ & $25 \cdot 5^{*}$ & $\begin{array}{r}13 \cdot 7 \\
2 \cdot 5\end{array}$ \\
\hline $\begin{array}{l}\text { Migraine } \\
\text { Dizziness, giddiness, } \\
\text { Vertiginous symptoms } \\
\text { Syndromes related to the } \\
\text { cervical spine }\end{array}$ & $\begin{array}{l}143 \\
411 \\
162 \\
372\end{array}$ & $\begin{array}{l}346 \\
780 \cdot 4 \\
386 \\
722 \cdot 0 \\
722 \cdot 4,723\end{array}$ & $\left.\begin{array}{r}12 \cdot 8 \\
14 \cdot 7 \\
8 \cdot 5 \\
18 \cdot 7\end{array}\right\}$ & $23 \cdot 2^{*}$ & $\left.\begin{array}{l}5 \cdot 3 \\
8 \cdot 7 \\
3 \cdot 9 \\
9 \cdot 4\end{array}\right\}$ & $12 \cdot 6^{*}$ & $\left.\begin{array}{r}8 \cdot 2 \\
10 \cdot 0 \\
4 \cdot 9 \\
11 \cdot 7\end{array}\right\}$ & $14.9^{*}$ & $\begin{array}{l}3 \cdot 5 \\
3 \cdot 5 \\
4 \cdot 8 \\
5 \cdot 2\end{array}$ \\
\hline $\begin{array}{l}\text { Prolapse or degeneration of } \\
\text { lumbar disc, sciatica }\end{array}$ & 373 & $\begin{array}{l}722 \cdot 1 \mathrm{pt} \\
722 \cdot 5 \mathrm{pt} \\
724 \cdot 3\end{array}$ & $24 \cdot 1$ & & $7 \cdot 3$ & & $10 \cdot 1$ & & $11 \cdot 7$ \\
\hline $\begin{array}{l}\text { Epilepsy } \\
\text { Convulsions } \\
\text { Faint, syncope } \\
\text { Cerebrovascular disease }\end{array}$ & $\begin{array}{l}142 \\
410 \\
416 \\
196\end{array}$ & $\begin{array}{l}345 \\
780 \cdot 3 \\
780 \cdot 2 \\
430-434, \\
436-438(\text { not } 437 \cdot 2)\end{array}$ & $\left.\begin{array}{r}9.0 \\
0.7 \\
5.6 \\
14.9 \\
4\end{array}\right\}$ & $19 \cdot 9^{*}$ & $\left.\begin{array}{l}1 \cdot 1 \\
0 \cdot 4 \\
4 \cdot 0 \\
2 \cdot 4\end{array}\right\}$ & $4.0^{*}$ & $\begin{array}{l}3 \cdot 5 \\
0 \cdot 5 \\
4 \cdot 2 \\
4 \cdot 1\end{array}$ & $6 \cdot 4^{*}$ & $\begin{array}{r}13 \cdot 7 \\
31.5 \\
7.9 \\
20 \cdot 4\end{array}$ \\
\hline $\begin{array}{l}\text { Transient cerebral ischaemia } \\
\text { Disturbance of sensation, } \\
\text { paraesthesiae }\end{array}$ & $\begin{array}{l}197 \\
413\end{array}$ & $\begin{array}{l}435 \\
782.0\end{array}$ & $\begin{array}{l}5.0 \\
3.5\end{array}$ & & $\begin{array}{l}1 \cdot 6 \\
2 \cdot 3\end{array}$ & & $\begin{array}{l}2 \cdot 3 \\
2 \cdot 6\end{array}$ & & $\begin{array}{l}11 \cdot 1 \\
11 \cdot 1\end{array}$ \\
\hline $\begin{array}{l}\text { Organic senile and pre-senile } \\
\text { psychoses }\end{array}$ & 100 & 290 & $6 \cdot 1$ & & 0.9 & & $2 \cdot 1$ & & $16 \cdot 7$ \\
\hline $\begin{array}{l}\text { Parkinson's disease } \\
\text { Multiple sclerosis } \\
\text { Involuntary movement } \\
\text { Disturbance of speech } \\
\text { Head injury without skull } \\
\text { fracture }\end{array}$ & $\begin{array}{l}140 \\
141 \\
412 \\
415 \\
481\end{array}$ & $\begin{array}{l}332 \\
340 \\
781 \cdot 1 \\
748 \cdot 3-784 \cdot 5 \\
850-854\end{array}$ & $\begin{array}{l}5 \cdot 3 \\
4 \cdot 5 \\
0 \cdot 8 \\
1 \cdot 1 \\
5 \cdot 1\end{array}$ & & $\begin{array}{l}0.4 \\
0.1 \\
0.5 \\
0.6 \\
3.9\end{array}$ & & $\begin{array}{l}1 \cdot 4 \\
0.8 \\
0.6 \\
0.8 \\
4 \cdot 0\end{array}$ & & $\begin{array}{l}12 \cdot 2 \\
15 \cdot 4 \\
12 \cdot 3 \\
27 \cdot 9 \\
12 \cdot 3\end{array}$ \\
\hline $\begin{array}{l}\text { Fracture of skull and facial } \\
\text { bones }\end{array}$ & 460 & $800-804$ & $1 \cdot 1$ & & 0.6 & & 0.7 & & $25 \cdot 8$ \\
\hline $\begin{array}{l}\text { Other diseases of the nervous } \\
\text { system } \\
\text { (Facial palsy) } \\
\text { (Primary cerebral tumour) }\end{array}$ & 144 & Rem. 320-359 & $10 \cdot 3$ & & $3 \cdot 3$ & & $\begin{array}{r}4 \cdot 8 \\
(0 \cdot 3) \\
(0 \cdot 1)\end{array}$ & & $18 \cdot 1$ \\
\hline
\end{tabular}

Notes

1. Table numbers in brackets in column headings refer to those of Third National Morbidity Survey.

2. College code = diagnostic code of Royal College of General Practitioners. ICD = International Classification of Diseases (Ninth Revision).

3. Figures in brackets in columns 6 and 7 are derived from Second National Morbidity Survey when equivalent data are not available from the Third Survey.

4. Figures marked with an asterisk indicate the sum of adjacent bracket figures for very similar conditions, about which it might reasonably be said that there was some doubt about the accuracy of coding.

5. Disorders have been ranked in order according to the figures in Column 6 (Patients consulting — risks per 1000 persons at risk, taking into account Note 4, with the exception that convulsions, faint and syncope have been placed next to epilepsy.

available in the Third National Morbidity study for some neurological disorders. In combination with the data from table 1, referral rates per 1000 can be calculated for these disorders. Table 2 lists the common neurological disorders for which referral rates are available in the Third National Morbidity Survey, ranked in order of numbers of patients referred from general practice for a further opinion. The sum of the figures in column 6 indicates that $7 \cdot 11$ patients per 1000 with these neurological disorders will be referred ( 5.32 excluding lumbar and spinal syndromes).

Table 3 ranks in column 2 those neurological disorders for which referral rates are available in the Third National Morbidity Survey in order of rate referred per 1000 population. In column 3 is listed the rank order of the same 10 diagnoses for new patients as seen by 13 consultant neurologists in one week in the UK in $1986 .^{5}$ The relative low ranking of cervical and spinal pain syndromes and giddiness among neurological specialist consultations presumably reflects that many patients with these disorders are referred to orthopaedic and ear, nose and throat consultants respectively.

\section{Discussion}

There have been a number of studies of the neurological content of family practice ${ }^{4-9}$ but the enormous amount of data collected for the Third National Morbidity Survey on over 300000 person years at risk makes these data unique. In the studies of Murray, ${ }^{6}$ of Marsland, ${ }^{7}$ of Miller $^{8}$ and of 
Table 2 Calculation of numbers of patients with various neurological and other disorders referred from general practitioner

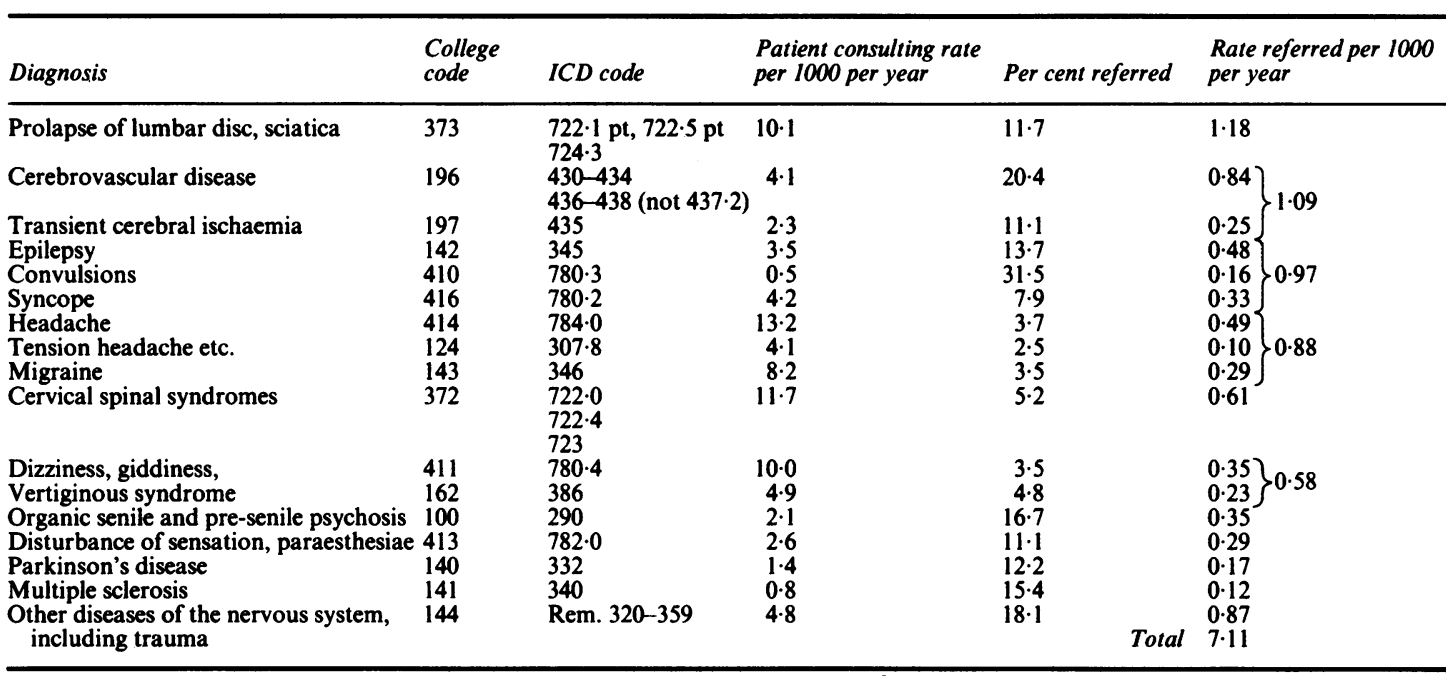

Based on Tables 11, 18 and 13 (microfiches) of the Third National Morbidity Survey. ${ }^{2}$

Table 3 Rank order of neurological disorders referred from general practice, compared with the rank order of those same disorders seen by 13 UK neurologists. ${ }^{5}$

\begin{tabular}{|c|c|c|c|}
\hline & $\begin{array}{l}\text { Referred from } \\
\text { general practice }\end{array}$ & $\begin{array}{l}\text { Seen by } \\
\text { neurologists }\end{array}$ & ర \\
\hline $\begin{array}{l}\text { Prolapse or degeneration of lumbar disc, sciatica } \\
\text { Cerebrovascular disease, transient cerebral ischaemia } \\
\text { Epilepsy, convulsions, faint, syncope } \\
\text { Headache, tension headache and migraine } \\
\text { Syndromes related to the cervical spine } \\
\text { Dizziness, giddiness, vertiginous syndromes } \\
\text { Organic senile and pre-senile psychosis (dementia) } \\
\text { Disturbance of sensation, paraesthesiae } \\
\text { Parkinson's disease } \\
\text { Multiple sclerosis }\end{array}$ & $\begin{array}{r}1 \\
2 \\
3 \\
4 \\
5 \\
6 \\
7 \\
8 \\
9 \\
10\end{array}$ & $\begin{array}{l}5 \\
3 \\
2 \\
1 \\
5 \\
6 \\
8 \\
7 \\
7\end{array}$ & $\begin{array}{l}\frac{0}{0} \\
\frac{1}{2} \\
\underline{2}\end{array}$ \\
\hline
\end{tabular}

Note Neurologists did not code "disorders of sensation, paraesthesiae", but peripheral nerve disorders including Bell's palsy and nerve entrapment ranked third in over-all frequency of neurological encounter, and anxiety, depression and personality disorders ranked fifth.

Papapetropoulos, ${ }^{4}$ headaches, migraine, seizure disorders and cerebrovascular disease all rank high as they do here. The syndromes listed in table 3 rank high in clinical importance in both family practice and in neurological practice. Undergraduate training of students, and post-graduate training of general practitioners by neurologists could usefully concentrate on the management of these disorders, although both students and family doctors must have some knowledge of the less common diseases.

The calculations shown in table 2 reveal that $7 \cdot 11$ patients per 1000 are referred from general practice for a further opinion for those common disorders listed in that table (5.32 per 1000 excluding spinal pain syndromes). The Association of British Neurologists has recently recommended that there be one neurologist per 200000 . This suggests a potential annual work load of $(5.32 \times 200)=1064$ consultations or $(7 \cdot 11 \times 200)=1422$ consultations per neurologist for these conditions alone, let alone the many other neurological disorders for which referral rates are not available.

The low referral rates from general practice to hospital shown in tables 1 and 2 reflect the very considerable burden of neurological illness managed in the community by general practitioners, who act as "gatekeepers"' and control access to specialist care. That general practitioners only refer $3.5 \%$ of patients with giddiness and migraine (table 1) is no doubt a relief to hard pressed UK neurologists, but it is clear that a small shift in referral patterns for such common conditions could disastrously overburden present consultant resources. On the other hand, neurologists may be surprised that referral rates for important 
neurological illness such as cerebrovascular disease are so low. Although there is very considerable variation in referral rates from different general practitioners, ${ }^{1011}$ it seems probable that referral rates to neurologists in the UK reflect consultant availability rather than need. Equally, the ready availability of neurologists in the US, where the number per million population is already nine times higher, and where it is suggested that many more are needed, ${ }^{5}$ indicates that many US neurologists are providing care that in the UK is provided by a family doctor. There are as yet few measures of clinical outcome, other than mortality, that can measure the impact of care upon the outcome of many disabling illnesses. Research should be undertaken to measure the increment in quality of care provided by neurologists over and above that provided by primary care physicians.

\section{References}

1 Studies on Medical and Population Subjects No 14, Vols 1-3. London: HMSO, 1958.

2 Office of Population Censuses and Surveys, Royal College of General Practitioners, Department of Health and Social Security. Morbidity statistics from general practice: second national study 1970-1971. London: HMSO, 1974.

3 Royal College of General Practitioners and Office of Population Censuses and Surveys. Department of Health and Social Security. 1981-1982. Morbidity statistics from general practice. London: HMSO, 1986.

4 Papapetropoulos T, Tsibre E, Pelekoudas V. The neurological content of general practice. $J$ Neurol Neurosurg Psychiatry 1989;52:434-5.

5 Hopkins A, Menken M, DeFriese G. A record of patient encounters in neurological practice in the United Kingdom. J Neurol Neurosurg Psychiatry 1989;52:436-8.

6 Murray TJ. Concepts in undergraduate neurological teaching. Clin Neurol Neurosurg 1976;79:275-84.

7 Marsland DW, Wood M, Mayo I. The content of family practice. J Fam Pract 1976;3:23-74.

8 Miller JR. The neurologic content of family practice. Implications for neurologists. Arch Neurol 1986; 43:286-8.

9 Eisenberg JM. The internist as gatekeeper. Ann Int Med 1985;102:537-42.

10 Walkin O, Smith AG. Variation in general practitioners' referral rate to consultants. J Royal Coll Gen Pract 1987;37:350-3.

11 Crombie DL, Fleming DM. General practitioner referrals to hospital: the financial implications of variability. Health Trends 1988;20:53-6.

\section{Cobb's views on functional and organic illness}

Physicians still tenaciously cling to the old dichotomy of two categories of illness: functional and organic. Professor Stanley Cobb, Bullard Professor of Neuropathology at Harvard, who preceded Raymond Adams, expatiated eloquently on this topic in his model introductory book, now sadly neglected by many students of Neurology.

"The term 'functional' is frequently misused to mean 'psychogenic.' This is a barbarism of the clinic, but has become almost routine out-patient slang. 'Functional' is a useful word in physiology and architecture. It should not be spoiled by other less acceptable usages. 'Organic' is used in a hazy way to mean that since 'organs' are involved there is something 'really wrong.' More specifically the users of 'organic' usually mean in psychiatry that there is a lesion of the brain. ('Lesion' being a visible abnormality.) If they mean this, why not say definitely what organ is meant and speak of 'cerebral lesions'? . .

In a provocative fashion which would not please all modern philosophical concepts of the brain-mind relationship he averred:

"1. No biological process goes on without change in structure;

2. Wherever the brain functions there is organic change;

3. The brain is the organ of the mind.

If we accept these three we must admit that 'organic' change takes place whenever a person has a thought. This is an important function of the brain. All function is organic, so the slang use of the term 'organic' or 'functional' is meaningless. If a line is drawn arbitrarily, its position is ordained by the point to which technology has advanced in the year. . In other words, the line between 'organic' and 'functional' (and between physical and mental is an artefact."

JMS PEARCE

Reference

Cobb S. Foundations of Neuropsychiatry. 6th edn. Baltimore, Williams \& Wilkins Co, 1958. 124-7. 